\title{
SEROLOGICAL EVIDENCE OF EXPOSURE TO Ehrlichia canis IN CATS
}

\section{EVIDÊNCIAS SOROLÓGICAS DA EXPOSIÇÃO DE GATOS A Ehrlichia canis}

\author{
Mariana Campos Fontalvo ${ }^{1}$ \\ Isis Assis Braga² \\ Daniel Moura Aguiar² \\ Mauricio Claudio Horta ${ }^{1 *}$ \\ ${ }^{1}$ Universidade Federal do Vale do São Francisco, Petrolina, PE, Brasil. \\ Universidade Federal do Mato Grosso, Cuiabá, MT, Brasil. \\ *Autor para correspondência - horta.mc@hotmail.com
}

\begin{abstract}
The aim of the present study was to estimate the occurrence of Ehrlichia canis in cats from the semiarid region of Northeast of Brazil. Sera of 101 healthy cats were submitted by Indirect Immunofluorescence Assay (IFA), and considered positive when antibody titers $\geq 40$ were obtained. Seroprevalence of $35.6 \%$ (36/101) was found, with the following titers: 40 (15 animals); 160 (6); 320 (1); 640 (3), and 2,560 (11). No statistical differences were observed when comparing county of origin, gender, age, breed, and modus vivendi (pet and stray cats), and no ticks were observed in any of the cats. This study revealed exposure to E. canis in cats of the Semiarid Northeast of Brazil.
\end{abstract}

Keywords: Caatinga; ehrlichiosis; feline; hemoparasite; semiarid.

\section{Resumo}

O objetivo do presente estudo foi estimar a ocorrência de Ehrlichia canis em gatos na região semiárida do Nordeste. Soros de 101 gatos saudáveis foram submetidos à Reação de Imunofluorescência Indireta (RIFI), sendo considerados positivos títulos $\geq 40$. Soroprevalência de 35,6\% (36/101) foi encontrada, com os seguintes títulos: 40 (15 animais); 160 (6); 320 (1); 640 (3) e 2560 (11). Não foram observadas diferenças estatísticas quanto ao município de origem, gênero, faixa etária, raça e modus vivendi (gatos domiciliados e errantes) e não foram observados carrapatos em qualquer um dos animais testados. Este estudo revelou exposição de gatos a E. canis na região semiárida do nordeste brasileiro.

Palavras-chave: Caatinga; erliquiose; felinos; hemoparasita; semiárido.

Received on: February $4^{\text {th }}, 2015$

Accepted on: March 1 $1^{\text {st }}, 2016$

\section{Introduction}

Ehrlichia sp. is a gram-negative, pleomorphic, obligate intracellular bacteria, belonging to Anaplasmataceae family, Rickettsiales order, that affects leukocytes and thrombocytes, and potentially 
infects a large variety of mammal species ${ }^{(1)}$. Transmission to the host occurs predominantly via vector through the bite of an infected tick, an event that can be attributed to the high prevalence of ehrlichiosis in tropical and subtropical regions, due to the geographical distribution of vectors associated to transmissibility ${ }^{(2)}$.

Indirect Immunofluorescence Assay (IFA) is traditionally used for the diagnosis of human and canine ehrlichiosis $^{(3)}$, and can also be used for diagnosis of feline ehrlichiosis ${ }^{(4)}$.

The first evidence for naturally occurring ehrlichiosis in cats was provided in 1986 by Charpentier and Groulade in France ${ }^{(5)}$. In Brazil, the first report was in 1998, by hematoscopy, through morulae observation of Ehrlichia sp. in leukocytes of a cat with clinical signs similar to those described in dogs with this disease ${ }^{(6)}$.

Ehrlichia sp. has been described in wild and domestic felids in various regions of the world, through hematoscopy, serology, and molecular techniques, feline ehrlichiosis being caused especially by $E$. canis $^{(7-16)}$. However, most surveys regarding E. canis occur in dogs and the reports about its occurrence in cats still remain scarce ${ }^{(4)}$.

Rhipicephalus sanguineus is the most important tick that parasitizes dogs in Brazil ${ }^{(17)}$. Although rarely found in cats, this tick is seen as the main vector of feline ehrlichiosis ${ }^{(18)}$. Predominant signs reported in cats include fever, anorexia, and lethargy. Myalgia, dyspnea, anemia, thrombocytopenia, and pancytopenia have been described as well. However, in most cases, the cats are asymptomatic ${ }^{(8,}$ 19).

Little is known about the exposure of the Brazilian feline population to E. canis because most studies focus on canine infections ${ }^{(20)}$. The present study aimed to verify the occurrence of anti-E. canis antibodies in cats and the possible associated risk factors in the counties of Juazeiro, Bahia State (BA), and Petrolina, Pernambuco State (PE), located in the middle region of the São Francisco Valley, Semiarid of Northeast of Brazil, belonging to Petrolina-Juazeiro Pole of the Integrated Network for Economic Development.

\section{Materials and methods}

This cross-sectional study was conducted in the counties of Juazeiro, BA ( $9^{\circ} 24$ '42'S; $\left.40^{\circ} 29^{\prime} 55^{\prime \prime} \mathrm{W}\right)$ and Petrolina, PE ( $9^{\circ} 23^{\prime} 55^{\prime}$ 'S, $\left.40^{\circ} 30^{\prime} 3^{\prime \prime} \mathrm{W}\right)$, semiarid tropical weather and Caatinga biome region.

From September 2012 to July 2013, convenience sampling was conducted, corresponding to 101 clinically healthy cats without restriction of age, breed or sex, originated from routine vaccines or other periodic control practices of a veterinary clinic, and animals from the Center of Zoonosis Control of both counties.

Peripheral blood samples were collected from the jugular, left or right cephalic vein, in dried tubes, properly identified, then centrifuged at 3,500 rpm for 10 min to obtain the serum, within 24 hours after collected. Sera were stored in $1.5 \mathrm{~mL}$ microtubes at $-20{ }^{\circ} \mathrm{C}$ until examination. Information about county of origin, sex, age, breed, and modus vivendi (pet and stray cat) were obtained. The samples were collected following the ethical standards of animal experimentation established by the Committee of Ethics and Deontology Studies and Research of the Federal University of São Francisco Valley (protocol number 11/161012).

The occurrence of anti-E.canis IgG antibodies was assessed by IFA, using E. canis strain Cuiabá $16^{(21)}$ as antigen with the cut-off point at an initial dilution of $1: 40^{(9,22,23)}$. Commercial fluorescein 
isothiocyanate-conjugated anti-cat IgG (Sigma-Aldrich, USA) was used as conjugate at a dilution of 1:1000, and the antigen preparation and IFA technique were performed as previously described ${ }^{(24)}$. Both positive and negative control sera were included in each assay.

Statistical evaluation was carried out by the Chi-Square test $\left(\mathrm{X}^{2}\right)$ or Fischer's exact test with a 95\% confidence interval.

\section{Results}

Among the 101 sampled animals, 56 (55.4\%) cats were from Juazeiro (BA), while 45 (44.6\%) were from Petrolina (PE); 59 (58.4\%) were female and $42(41.6 \%)$ were male. A total of $63(62.4 \%)$ cats were kittens (12 months of age or less) and 38 (37.6\%) were adults, among whom there were 4 seniors (over 7 years old); 95 (94.1\%) were of undefined breed, while six (5.9\%) were Siamese breed; 47 $(46.5 \%)$ were pets, versus $54(53.5 \%)$ stray cats. Seroprevalence of cats for E. canis in this study was $35.6 \%$, and the positive samples showed the following titers: 40 (15 animals); 160 (6); 320 (1); 640 (3), and 2,560 (11) (Table 1).

Table 1. Titers of anti-Ehrlichia canis antibodies in cats from semiarid region of northeastern Brazil obtained by Indirect Immunofluorescence Assay from September 2012 to July 2013

\begin{tabular}{lcc}
\hline IFA titers & $\boldsymbol{n}$ & $\%$ \\
\hline Negative & 65 & 64.3 \\
40 & 15 & 14.9 \\
160 & 6 & 5.9 \\
320 & 1 & 1.0 \\
640 & 3 & 3.0 \\
2560 & 11 & 10.9 \\
\hline Total & 101 & $100 \%$ \\
\hline
\end{tabular}

No significant differences ( $p>0.05$ ) were found for any of the analyzed variables (Table 2).

Table 2. Ehrlichia canis serology in cats from the semiarid northeast Brazil from September 2012 to July 2013: county of origin, gender, age, breed and modus vivendi

\begin{tabular}{|c|c|c|c|c|c|}
\hline \multirow{2}{*}{ Epidemiological aspects } & \multicolumn{2}{|c|}{ Tested animals } & \multicolumn{2}{|c|}{ Seropositive animals } & \multirow{2}{*}{$\mathbf{P}$} \\
\hline & $N$ & $\%$ & $n$ & $\%$ & \\
\hline \multicolumn{6}{|l|}{ County of origin } \\
\hline Juazeiro, BA & 56 & 55.4 & 18 & 32.1 & \multirow{2}{*}{0.541} \\
\hline Petrolina, PE & 45 & 44.6 & 18 & 40.0 & \\
\hline \multicolumn{6}{|l|}{ Gender } \\
\hline Male & 42 & 41.6 & 14 & 33.3 & \multirow[t]{2}{*}{0.842} \\
\hline Female & 59 & 58.4 & 22 & 37.3 & \\
\hline \multicolumn{6}{|l|}{ Age } \\
\hline Younger ( $\leq 12$ months) & 63 & 62.4 & 18 & 28.6 & \multirow{2}{*}{0.089} \\
\hline Adults (>12 months) & 38 & 37.6 & 18 & 47.4 & \\
\hline \multicolumn{6}{|l|}{ Breed } \\
\hline Undefined & 95 & 94.1 & 34 & 35.8 & \multirow{2}{*}{0.750} \\
\hline Defined & 6 & 5.9 & 2 & 33.3 & \\
\hline \multicolumn{6}{|l|}{ Modus vivendi } \\
\hline Pet & 47 & 46.5 & 13 & 27.7 & \multirow[t]{2}{*}{0.175} \\
\hline Stray & 54 & 53.5 & 23 & 42.6 & \\
\hline
\end{tabular}




\section{Discussion}

IFA results obtained in the present study are in accordance with Braga et al. ${ }^{(23)}$, who found seropositivity of $41.5 \%$ to E. canis (cut-off 1:40) among 93 pet cats from Cuiabá, Mato Grosso State (tropical wet and dry climate and Cerrado biome region). This similarity suggests the dissemination of the agent within the host population may be associated with abiotic factors (climate), whereas the higher temperature favors the dispersion of ticks and, hence, the vector-borne diseases ${ }^{(2,25)}$.

Braga et al. ${ }^{(13)}$ found $5.5 \%$ of individuals reagent (cut-off 1:64) to the same agent among 200 pet cats in São Luís, Maranhão State (tropical monsoon climate region, palm tree forest biome). This prevalence is in agreement with the canine ehrlichiosis profile at the locality ${ }^{(20)}$, indicating that the epidemiological behavior of feline ehrlichiosis is similar to the canine ehrlichiosis in that region, as described in Cuiabá by Braga et al. ${ }^{(14)}$. We found the same association comparing seropositivity in cats (present study) and $\operatorname{dog} \mathrm{s}^{(20)}$ at matching geographic location. Related epidemiological profile between cats and dogs was also found in Central Italy ${ }^{(22)}$ and Portugal ${ }^{(16,26,27)}$. This association suggests once more that the major factor implicated in ehrlichiosis prevalence is that associated to the vector biology in a tick-free environment rather than host factors, including host species ${ }^{(28)}$.

However, other reports found lower rates in cats than those detected in dogs, conjecturing that cats might be more resistant to ehrlichiosis ${ }^{(29)}$, or cats are infected less frequently as they remove ticks during self-cleaning ${ }^{(22)}$.

André et al. ${ }^{(30)}$ detected positivity of $21 \%$ in Ehrlichia spp. in wild captive felids in Brazil, among which $52 \%$ contained ehrlichial DNA closely related to E. chaffeensis, a species associated to human monocytic ehrlichiosis ${ }^{(31)}$.

None of the cats were parasitized by ticks at the time of blood collection; although, some owners have reported the presence of ticks on their animals elsewhere. Exposure to ticks has been reported in about $30 \%$ of feline ehrlichiosis cases ${ }^{(32)}$. In the present survey, information about vector exposure is not complete. This lack of data precludes definitive assertions regarding this association.

None of cats in the present study presented clinical signs, such as those found by Correa et al. ${ }^{(33)}$. It is known that clinical cases of ehrlichiosis in these animals are not common ${ }^{(8)}$. This aspect suggests that the felines might act as potential asymptomatic reservoirs and sentinels of E. canis and other vectorborne agents ${ }^{(16,33)}$.

No statistical differences were observed when comparing the presence of antibodies in cats according to the county of origin, gender, age, breed, and modus vivendi, similarly to previous reports ${ }^{(14,22)}$. However, the high frequency of positive adult and stray cats demonstrated in this work should be explained by the higher time of exposure and higher possibility of contact with the vectors, respectively.

\section{Conclusion}

These results revealed the cats of Semiarid Northeast of Brazil were exposed to E. canis. Considering this fact, adopting effective prophylaxis and control measures against the vector becomes necessary to prevent infection of cats by E. canis and other vector-borne diseases, as well as their potential transmission to other animal species and to human beings.

Further investigations about E. canis and other vector-borne agents are needed to better understand 
and define the role of cats in the epidemiology of ehrlichiosis.

\section{Acknowledgements}

To Dr. Luiz Lucionildo, Secretaria Municipal de Saúde, Centro de Controle de Zoonoses, Juazeiro, BA; Dr $^{\mathrm{a}}$. Michele Paschoal, Secretaria Municipal de Saúde, Centro de Controle de Zoonoses, Petrolina, PE. We thank Fundação de Amparo à Pesquisa do Estado de Mato Grosso (FAPEMAT) and Conselho Nacional de Desenvolvimento Científico e Tecnológico (CNPq) for the scholarship of I.A. Braga and Scientific Productivity Grant awarded to D. M. Aguiar.

\section{References}

1. Dumler JS, Barbet AF, Bekker CPJ, Dasch GA, Palmer GH, Ray SC, et al. Reorganization of genera in the families Rickettsiaceae and Anaplasmataceae in the order Rickettsiales: unification of some species of Ehrlichia with Anaplasma, Cowdria with Ehrlichia and Ehrlichia with Neorickettsia, descriptions of six new species combinations and designation of Ehrlichia equi and 'HGE agent' as subjective synonyms of Ehrlichia phagocytophila. Int J Syst Evol Microbiol 2001; 51: 2145-2165.

2. Cohn LA. Ehrlichiosis and related infections. Vet Clin North Am Small Anim Pract 2003; 33(4) 863-884.

3. Dumler JS, Madigan JE, Pusterla N, Bakken JS. Ehrlichioses in humans: epidemiology, clinical presentation, diagnosis, and treatment. Clin Infect Dis 2007; 45: S45-51.

4. Little, S. E. Ehrlichiosis and Anaplasmosis in dogs and cats. Vet Clin North Am Small Anim Pract 2010; 40(6): 1121-1140.

5. Charpentier F, Groulade P. Un cas d'ehrlichiose probable chez le chat. Bull Acad Vet Fr. 1986; 59: 287-290.

6. Almosny NRP, Almeida LE, Moreira NM, Massard CL. Erliquiose clínica em gato (Felis catus). Rev Bras Cienc Vet 1998; 5: 82-83.

7. Matthewman L, Kelly PJ, Wray K. Antibodies in cat sera from southern Africa react with antigens of Ehrlichia canis. Vet Rec 1996; 138(15): 364-365.

8. Breitschwerdt EB, Abrams-Ogg ACG, Lappin MR, Bienzle D, Hancock SI, Cowan SM, Clooten JK, Hegarty BC, Hawkins EC. Molecular evidence supporting Ehrlichia canis-like infection in cats. J Vet Intern Med 2002; 16: 642-649

9. Aguirre E, Tesouro MA, Amusategui I, Rodríguez-Franco F, Sainz A. Assessment of feline Ehrlichiosis in Central Spain using serology and a polymerase chain reaction technique. Ann NY Acad Sci 2004; 1026: 103-105.

10. Filoni C, Catão-Dias JL, Bay G, Durigon EL, Jorge RS, Lutz H, Hofmann-Lehmann R. First evidence of feline herpesvirus, calicivirus, parvovirus, and Ehrlichia exposure in Brazilian freeranging felids. J Wildl Dis 2006; 42(2): 470-477.

11. Tabar MD, Altet L, Francino O, Sánchez A, Ferrer L, Roura X. Vector-borne infections in cats: molecular study in Barcelona area (Spain). Vet Parasitol 2008; 151: 332-336. 
12. Sasaki H, Ichikawa Y, Sakata Y, Endo Y. Nishigaki K, Matsumoto K, Inokuma H. Molecular survey of Rickettsia, Ehrlichia, and Anaplasma infection of domestic cats in Japan. Ticks Tick Borne Dis 2012; 3: 307-310.

13. Braga MSCO, André MR, Freschi CR, Teixeira MCA, Machado RZ. Molecular and serological detection of Ehrlichia spp. in cats on São Luís Island, Maranhão, Brazil. Rev Bras Parasitol Vet 2012; 21(1) 37-41.

14. Braga IA, Santos LGF, Melo ALT, Jaune FW, Ziliani TF, Girardi AF, Aguiar DM. Hematological values associated to the serological and molecular diagnostic in cats suspected of Ehrlichia canis infection. Rev Bras Parasitol Vet 2013; 22(4) 470-474.

15. Tateno M, Nishio T, Sakuma M, Nakanishi N, Izawa M, Asari Y, Okamura M, Maruyama S, Miyama TS, Setoquchi A, Endo Y. Molecular epidemiologic survey of Bartonella, Ehrlichia, and Anaplasma infections in Japanese Iriomote and Tsushima Leopard cats. J Wildl Dis 2013; 49(3): 646-652.

16. Maia C, Ramos C, Coimbra M, Bastos F, Martins A, Pinto P, Nunes M, Vieira ML, Cardoso L, Campino L. Bacterial and protozoal agents of feline vector-borne diseases in domestic and stray cats from southern Portugal. Parasit Vectors 2014; 7:115.

17. Moraes-Filho J, Marcili A, Nieri-Bastos FA, Richtzenhain LJ, Labruna MB. Genetic analysis of ticks belonging to the Rhipicephalus sanguineus group in Latin America. Acta Trop 2011; 117(1): $51-55$.

18. Dryden MW, Payne PA. Biology and control of ticks infesting dogs and cats in North America. Vet Ther 2004; 5(2):139-54.

19. Stubbs CJ, Holland CH, Relf JS. Feline ehrlichiosis. Compend Contin Educ Vet 2000; 22(4): $307-18$.

20. Vieira RFC, Biondo AW, Guimarães AMS, Santos AP, Santos RP, Dutra LH, Diniz PP, Morais HA, Messick JB, Labruna MB, Vidotto O. Ehrlichiosis in Brazil. Rev Bras Parasitol Vet 2011; 20(1): $1-12$.

21. Aguiar DM, Zhang X, Melo ALT, Pacheco TA, Meneses AMC, Zanuto MS, Horta MC, Santarém VA, Camargo LM, McBride JW, Labruna MB. Genetic diversity of Ehrlichia canis in Brazil. Vet Microbiol 2013; 164(2013): 315-321.

22. Ebani VV, Bertelloni F. Serological evidence of exposure to Ehrlichia canis and Anaplasma phagocytophilum in Central Italian healthy domestic cats. Ticks Tick Borne Dis 2014; 5(6):668-71.

23. Braga IA, Santos LGF, Ramos DCS, Melo ALT, Mestre GLC, Aguiar DM. Detection of Ehrlichia canis in domestic cats in the central-western region of Brazil. Braz J Microb 2014; 45:641-645.

24. Aguiar DM, Saito TB, Hagiwara MK, Machado RZ, Labruna MB. Diagnóstico sorológico de erliquiose canina com antígeno brasileiro de Ehrlichia canis. Cienc Rural 2007; 37(3): 796-802.

25. Randolph SE. Tick ecology: processes and patterns behind the epidemiological risk posed by ixodid ticks as vectors. Parasitology 2004; 129: S37-65. 
26. Vilhena H, Martinez-Díaz VL, Cardoso L, Vieira L, Altet L, Francino, Pastor J, Silvestre-Ferreira AC. Feline vector-borne pathogens in the north and centre of Portugal. Parasit Vectors 2013; 6:99.

27. Cardoso L, Mendão C, Madeira de Carvalho L. Prevalence of Dirofilaria immitis, Ehrlichia canis, Borrelia burgdorferi sensu lato, Anaplasma spp. and Leishmania infantum in apparently healthy and CVBD-suspect dogs in Portugal - a national serological study. Parasit Vectors 2012; 5: 62.

28. Tanikawa A, Labruna MB, Costa A, Aguiar DM, Justiniano SV, Mendes RS, Melo AL, Alves CJ, Azevedo SS. Ehrlichia canis in dogs in a semiarid region of Northeastern Brazil: Serology, molecular detection and associated factors. Res Vet Sci 2013; 94(2013): 474-477.

29. Lappin MR, Griffin B, Brunt J, Riley A, Burney D, Hawley J, Brewer MM, Jensen WA. Prevalence of Bartonella species, haemoplasma species, Ehrlichia species, Anaplasma phagocytophilum, and Neorickettsia risticii DNA in the blood of cats and their fleas in the United States. J Feline Med Surg 2006; 8: 85-90.

30. André MR, Dumler JS, Scorpio DG, Teixeira RHF, Allegretti SM, Machado RZ. Molecular detection of tick-borne bacterial agents in Brazilian and exotic captive carnivores. Ticks Tick-borne Dis 2012; 3:247-253. doi: 10.1016/j.ttbdis.2012.04.002

31. Olano JP, Walker DH. Human ehrlichiosis. Med Clin N Am 2002; 86(2) 375-392.

32. Lappin MR. Update on Two Feline Parasites: Ehrlichia and Hemobartonella. Proceedings of the 25th Annual Feline Symposium Winn Feline Foundation, St. Louis, MO. 2003. Available from http:// www.winnfelinehealth.org/Pages/03_Lappin_Summ1_final.pdf

33. Correa ES, Paludo GR, Scalon MC, Machado JA, Lima ACQ, Pinto ATB, Thiebault JTL, Albernaz AP. Investigação molecular de Ehrlichia spp. e Anaplasma platys em felinos domésticos: alterações clínicas, hematológicas e bioquímicas. Pesq Vet Bras 2011; 31(10): 899-909. 